\title{
An Assessment of the Potential of Photovoltaic Lithium Solar Cells for Electricity Generation in Katsina State
}

\author{
Bashir Salisu
}

\begin{abstract}
A photovoltaic cell is a specialized semiconductor diode that concerts visible light into direct current(DC).Some PV cell can also convert Infrared (IR) or ultraviolet (U.V) radiation into DC electricity. In this research article a special pyranometer laboratory instrument (containing Prepared sample of Silicon,Si and Lithium,Li on a sample holder) was used to measured/assessed the Solar radiation in katsina state and determine the best /highest potential element between $\mathrm{Si}$ and $\mathrm{Li}$ in respect of energy production. The samples ware prepared in form of a thin-film using synthesis and characterization. It was stated in the literature silicon have been used industrially over decades in manufacturing photovoltaic cells, but it has a drawback of degrading over time, hence the idea of introducing another element $(\mathrm{Li})$ to replaced it.The results of this research was obtained from three(3) areas of katsina state:viz Daura, Funtua and Katsina.The result shows that: from Funtua loction Lithium thin-film absorbed an extra energy of $(4.6 \mathrm{kw} / \mathrm{m} 2)$ over Silicon, likewise in Daura and Katsina, there is a differences of (4.6 and 5.0) $\mathrm{kw} / \mathrm{m} 2$ which lithium have over silicon respectively.This gives Lithium priority to be used industrially over silicon.Also this result qulifies katsina state to be a very good location for solar power plant, since the visible light intesity is in good agreement with Standard Surface Solar Irradiation (SSI).

Index Terms- photovoltaic, pyranometer,lithium/silicon,solar thin-film,electricity.
\end{abstract}

\section{INTRODUCTION}

The solar energy is known to be relatively clean, environmentally accepted and replenishable (1). The rate at which the sun releases energy is about $2.93 \times 10^{19} \mathrm{kwh}$, if fraction of its energy is harnessed, Nigeria's energy problem could be regarded as a thing of the past.(2) Solar energy is a radiant light and heat from the Sun that is harnessed using a range of ever-evolving technologies such as solar heating, photovoltaics, solar thermal energy, solar architecture,

molten salt power plants and artificial photosynthesis.(8)Solar is a safe alternative which can replace current fossil fuels like coal

and gas for generation of electricity that produce air, water, and land pollution. Use of solar energy will eliminate these unsafe, unclean consequences from using conventional fossil fuels.(7) Hence in this research we tested new element in trying to find a lasting solution for energy problem in katsina and the country at large, since It is clearly stated in the

Bashir Salisu, Department of Basic and Applied Sciences,College of Science and Technology, Hassan Usman Katsina Polytechnic, Katsina, Nigeria literature that SILICON PV-CELLS has a degrading defect after a long time usage, That is why we want rectify/replace the PV-silicon cells with the newly made LITHIUM PV CELLS since LITHIUM ELEMENT has higher resistance to physical condition such as pressure, temperature and humidity(3).when compared with SILICON ELEMENT.

Phenomenon of Electricity Generation by Solar Panels

Photovoltaic solar panels generate direct current (DC) electricity. With DC electricity, electrons flow in one direction around a circuit. This example shows a battery powering a light bulb. The electrons move from the negative side of the battery, through the lamp, and return to the positive side of the battery. With AC (alternating current) electricity, electrons are pushed and pulled, periodically reversing direction, much like the cylinder of a car's engine. The below chart is the demonstration of the phenomenon. (4)

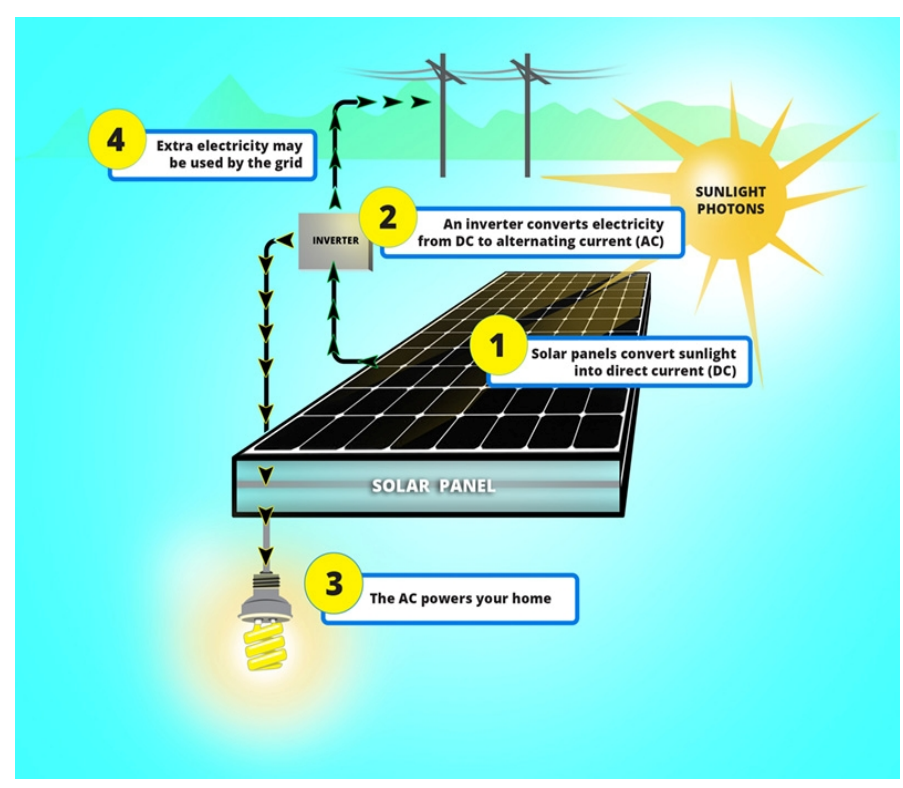

Fig. 1 Phenomenon of Electricity Generation by Solar Panels

A pyranometer is a type of actinometer used for measuring solar irradiance on a planar surface and it is designed to measure the solar radiation flux density $\left(\mathrm{W} / \mathrm{m}^{2}\right)$ from the hemisphere above within a wavelength range $0.3 \mu \mathrm{m}$ to $3 \mu \mathrm{m}$. 


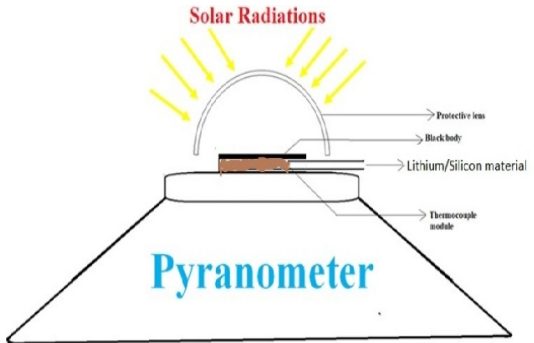

Fig.2 Schematic view of pyranometer

A photovoltaic cell (PV cell) is a specialized semiconductor diode that converts visible light into direct current (DC). Some PV cells can also convert infrared (IR) or ultraviolet (UV) radiation into DC electricity.

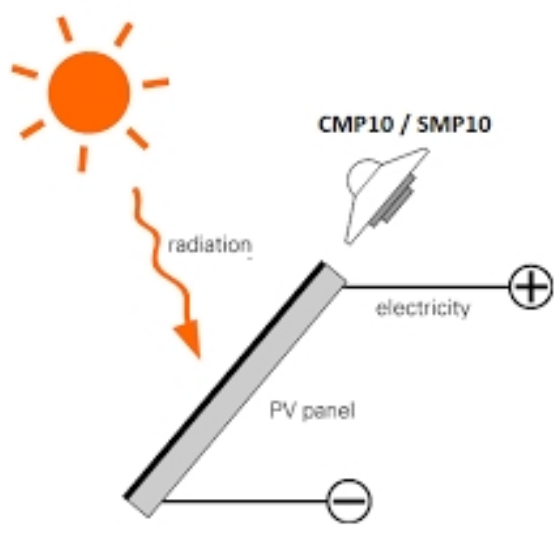

Fig.3 Schematic view of the photovoltaic cell

Like the other alkali metals, lithium has a single valence electron that is easily given up forming a cation, this is what make it a good conductor of electricity as well as highly reactive element. Lithium metal is soft enough to be cut with knife. When cut, it possesses a silvery white color that quickly changes to grey due to oxidation. This property is what make it very good in insolation/ absorption of radiant energy.

\section{Samples Preparation}

The lithium and silicon granules, were commercially obtained, then they were synthesis after diluted in $50 \mathrm{ml}$ Distilled water, then sonicated for 30 minutes, then centrifuge at the rate of $300 \mathrm{rpm}$, then the distilled water was decanted manually, then the aqueous solution was obtained ready annealing on a Hot plate with temperature of $80^{\circ} \mathrm{C}$ as can be seen below:
Fig.4 Skeletal view of the fabricated sample Lithium/Silicon thin film

Katsina State and its climatic variables

Katsina state is in the sub - Saharan tropical belt of Africa (Nigeria) within latitude of $\left(11^{0} 08^{1} \mathrm{~N}\right.$ and $\left.13^{0} 22^{1} \mathrm{~N}\right)$ and longitudes $\left(6^{0} 52^{1}\right.$ and $\left.9^{0} 20^{1} \mathrm{E}\right)$. The region is generally characterized by two distinct seasons, the wet (rainy) and Dry (Harmattan) seasons. The average air Density of katsina is $1.18 \mathrm{~kg} / \mathrm{m}^{3}$ which is a Higher temporal. Considering This location which involved high temperature, humidity and sunshine throughout the year make katsina a suitable place for application of solar devices.In general, the temperature of core of the sun is estimated to about $2 \times 10^{7} \mathrm{k}$, while the outmost layer is $600 \mathrm{k}$, ie the temperature of a black body. The sun itself is at $1.5 \times 10^{8} \mathrm{~km}$ from the earth and has a mass of $(1.991+-0.002) \times 10^{30} \mathrm{~kg}$. (5)

\section{MATERIAL AND METHOD:}

The fabricated lithium and silicon pyranometers devices were used in this experiment and the data obtained from each device were recorded in separate column for comparison. The pyranometer device $(\operatorname{Pr} D)$ has variables resistance which changes with light intensity that falls upon it. The PrD component consist of thermopile, protecting box, glass dome and radiation sensor. It was also modified to measure only a total global radiation there by filtering away the diffused radiation caused by air molecules, aerosol particles and cloud droplets towards receiving plane surface. The open field of every area measured was used as a base station to avoid the effects of shading cast by trees, building or electric poles. The Pr D device, out-function the Light Development Resistor (LDR) which can measure the whole beam and diffuse radiation which make it lesser in accuracy.

In this research, seven days was spent in each location of measurement between January to march, 2019, for taking the research data, as presented in the separate tables below.

Theoretical aspect of the research:

The clearness index of each location can be obtained by the used of the following relation:

$\mathrm{CL}=\mathrm{I}_{\mathrm{gr}} / \mathrm{I}_{\mathrm{SC}} \cos \mathrm{Z}(\mathrm{t}, \mathrm{L})$

Where $\mathrm{Cl}=$ Clearness index

$\mathrm{I}_{\mathrm{gr}}=$ global radiation intensity

$\operatorname{Cos} \mathrm{Z}(\mathrm{t}, \mathrm{L})=$ solar zenith angle at time $(\mathrm{t})$ and latitude

$$
\mathrm{I}_{\mathrm{SC}}=\text { solar intensity constant given by } 1367 \mathrm{w} / \mathrm{m}^{2} \text { ( 6) }
$$

The value of CL is used to determine the surface solar irradiation (SSI) which is very essential factor considered when finding a suitable location for solar power plant.(6)

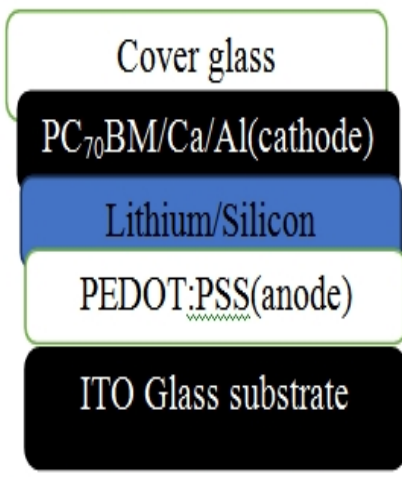




\section{Results Presentation:}

TABLE 1: Showing the $1^{\text {st }}$ Quarter measurement of Total instantaneous insolation for the seven days in the month of January 2019. Measured from 8:00am to 6:00pm (i.e 9 hours) each day, carried out at Funtua local government which represent the southern part of katsina state.

\begin{tabular}{|c|c|c|c|c|}
\hline DAY NO. & \begin{tabular}{l}
\multicolumn{1}{c}{ Lithium } \\
Pyranometer \\
Reading in $\mathrm{kWh} / \mathrm{m}^{2}$
\end{tabular} & $\begin{array}{l}\text { Silicon } \\
\text { Pyranometer } \\
\text { Reading } \\
\mathbf{k W h} / \mathbf{m}^{2}\end{array}$ & $\begin{array}{l}\text { Total temperature } \\
\text { recorded in Degree } \\
\text { Celsius }\left({ }^{\circ} \mathrm{C}\right)\end{array}$ & $\begin{array}{l}\text { Average } \\
\text { Temperature/Day } \\
\text { Degree Celsius }\left({ }^{\circ} \mathrm{C}\right)\end{array}$ \\
\hline 1 & 125.00 & 120.00 & 280 & 28.0 \\
\hline 2 & 131.00 & 130.00 & 310 & 31.0 \\
\hline 3 & 129.00 & 120.00 & 300 & 30.0 \\
\hline 4 & 130.00 & 130.00 & 295 & 29.0 \\
\hline 5 & 128.00 & 120.00 & 305 & 30.5 \\
\hline 6 & 132.00 & 130.00 & 309 & 30.9 \\
\hline 7 & 127.00 & 120.00 & 315 & 31.5 \\
\hline & 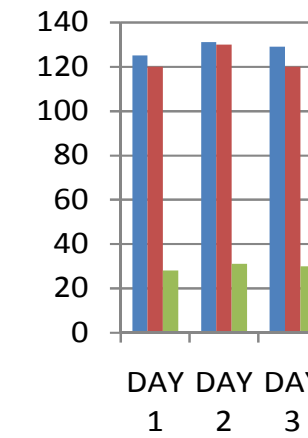 & $\begin{array}{l}\text { DAY DAY DAY DAY } \\
4 \quad 5 \quad 6 \quad 7\end{array}$ & $\begin{array}{l}\text { LITHIUM } \\
\text { SILICON } \\
\text { AVERAGE } \\
\text { TEMP.C }\end{array}$ & \\
\hline
\end{tabular}

Fig.5. Bar chart representing a raw data for table 1

TABLE 2: Showing the $2^{\text {nd }}$ Quarter measurement of Total instantaneous insolation for the seven days in the month of January 2019. Measured from 8:00am to 6:00pm (,i.e 9 hours) each day, carried out at Daura local government which represent Northern part the of katsina state.

\begin{tabular}{|c|c|c|c|c|}
\hline DAY NO. & \begin{tabular}{l}
\multicolumn{1}{c}{ Lithium } \\
Pyranometer \\
Reading \\
$\mathbf{k W h} / \mathbf{m}^{2}$
\end{tabular} & $\begin{array}{c}\text { Silicon Pyranometer } \\
\text { Reading in } \mathrm{kWh} / \mathrm{m}^{2}\end{array}$ & $\begin{array}{l}\text { Total temperature } \\
\text { recorded in Degree } \\
\text { Celsius }\left({ }^{\circ} \mathrm{C}\right)\end{array}$ & $\begin{array}{l}\text { Average } \\
\text { Temperature/Day } \\
\text { in Degree Celsius } \\
\left({ }^{\mathbf{O}} \mathrm{C}\right)\end{array}$ \\
\hline 1 & 150.00 & 150.00 & 310 & 31.0 \\
\hline 2 & 149.00 & 140.00 & 320 & 32.0 \\
\hline 3 & 145.00 & 140.00 & 331 & 33.1 \\
\hline 4 & 151.00 & 150.00 & 325 & 32.5 \\
\hline 5 & 148.00 & 140.00 & 300 & 30.0 \\
\hline 6 & 149.00 & 140.00 & 311 & 31.1 \\
\hline 7 & 150.00 & 150.00 & 300 & 30.0 \\
\hline
\end{tabular}

Source: Field Work 


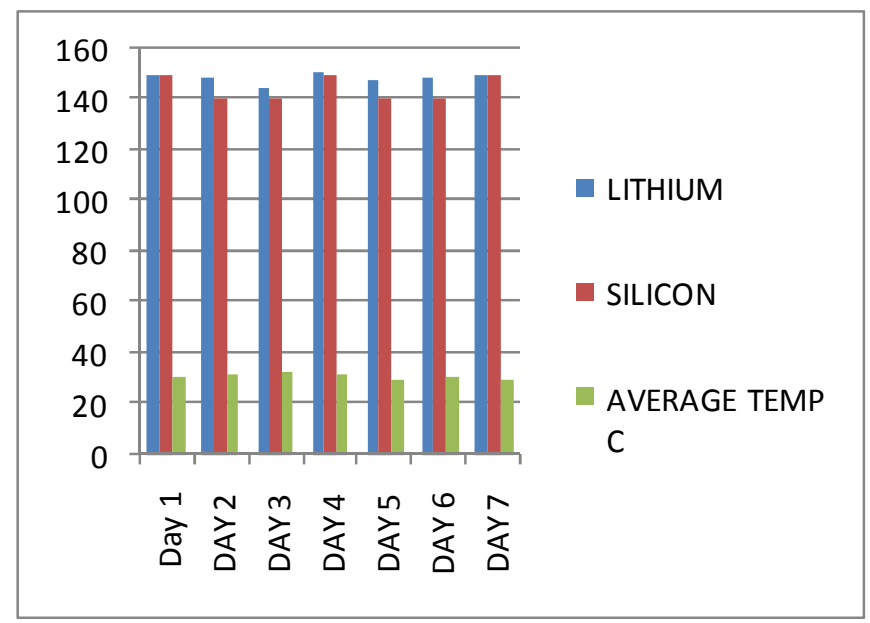

Fig.6 Bar chart representing a raw data for table 2

TABLE 3: Showing the $3^{\text {rd }}$ Quarter measurement of Total instantaneous insolation for the seven days in the month of January 2019. Measured from 8:00am to 6:00pm (i.e 9 hours) each day, carried out at Katsina local government which represent the Central part of katsina state.

\begin{tabular}{|c|c|c|l|l|}
\hline $\begin{array}{c}\text { DAY } \\
\text { NO. }\end{array}$ & $\begin{array}{l}\text { Lithium } \\
\text { Pyranometer } \\
\text { Reading } \\
\mathbf{k W h} / \mathbf{m}^{2}\end{array}$ & $\begin{array}{c}\text { Silicon Pyranometer } \\
\text { Reading in } \mathbf{k W h} / \mathbf{m}^{2}\end{array}$ & $\begin{array}{l}\text { Total temperature } \\
\text { recorded in Degree } \\
\text { Celsius }\left({ }^{\mathbf{O}} \mathbf{C}\right)\end{array}$ & $\begin{array}{l}\text { Average Temperature/ } \\
\text { Day in Degree Celsius }\left({ }^{\mathbf{O}} \mathrm{C}\right)\end{array}$ \\
\hline 1 & 143.00 & 140.00 & 300 & 30.0 \\
\hline 2 & 139.00 & 130.00 & 330 & 33.0 \\
\hline 3 & 141.00 & 140.00 & 310 & 31.0 \\
\hline 4 & 138.00 & 130.00 & 325 & 33.5 \\
\hline 5 & 144.00 & 140.00 & 330 & 33.5 \\
\hline 6 & 145.00 & 140.00 & 335 & 31.0 \\
\hline 7 & 135.00 & 130.00 & 310 & \\
\hline
\end{tabular}

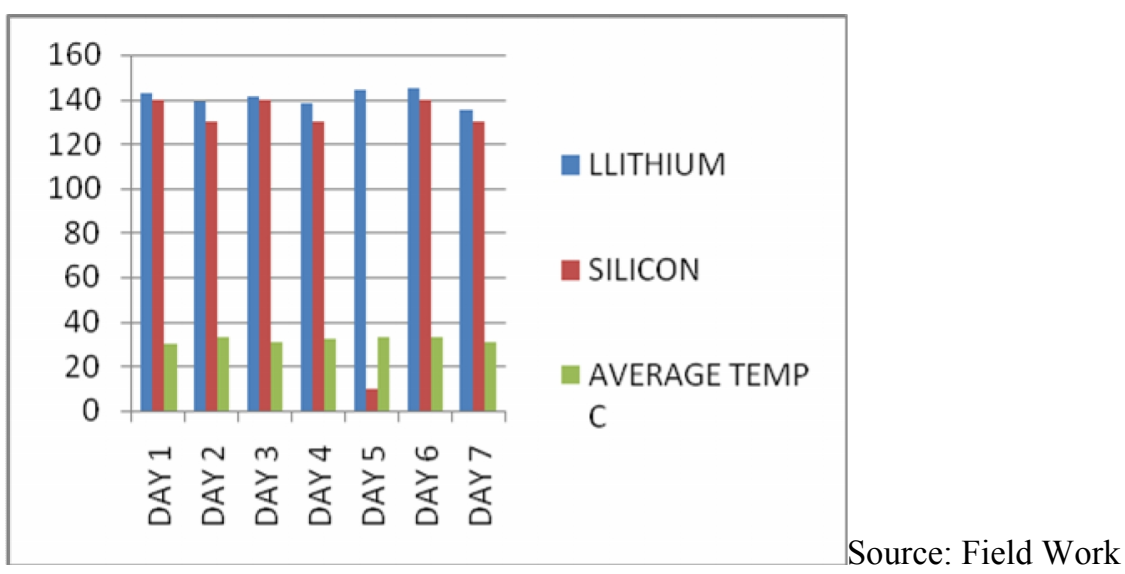

Fig.7. Bar chart representing a raw data for table 3

\section{RESULTS DISCUSSION:}

\section{From Table 1, and Figure 5}

The average differences (this can be obtained by summing up the reading of insolated energy of each element and dividing it by the number of days taken during the experiment) of insolation between the two element (ie $\mathrm{Li}$ and $\mathrm{Si}$ ) in table 1, can best be seen in the chart (figure 4) below, where lithium is having the value of $\left(148.9 \mathrm{kw} / \mathrm{m}^{2}\right)$ which is $51 \%$ and silicon goes with the $\left(144.3 \mathrm{kw} / \mathrm{m}^{2}\right)$ which is $49 \%$ that means there were difference of $4.6 \mathrm{kw} / \mathrm{m}^{2}$ between li and si .This indicate that Lithium absorbed an extra/additional sun-radiant energy of $4.6 \mathrm{kw} / \mathrm{m}^{2}$ in every week, and this resulted in losing the same energy when silicon was used. An average of $(4.6 \times 4=18.4) \mathrm{kw} / \mathrm{m}^{2}$ is being lost every month when silicon is used, which is a very great lost that need to be rectified. The same thing with the remaining station of measurement we equally have a great loss of energy when silicon is used, as can equally be deduced from their tables.

From the results, we also observed that: Katsina state can be a very good location for solar power location, this why because the intensity of sun-energy is in good agreement with the standard surface solar irradiation (SSI) (6) 


\section{$\mathrm{Li} / \mathrm{Si}$ insolation differences from Table 1}

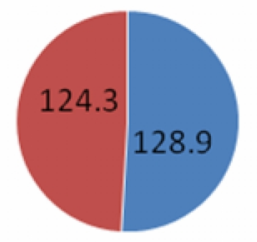

\section{- LITHIUM} - SILICON

Figure 8

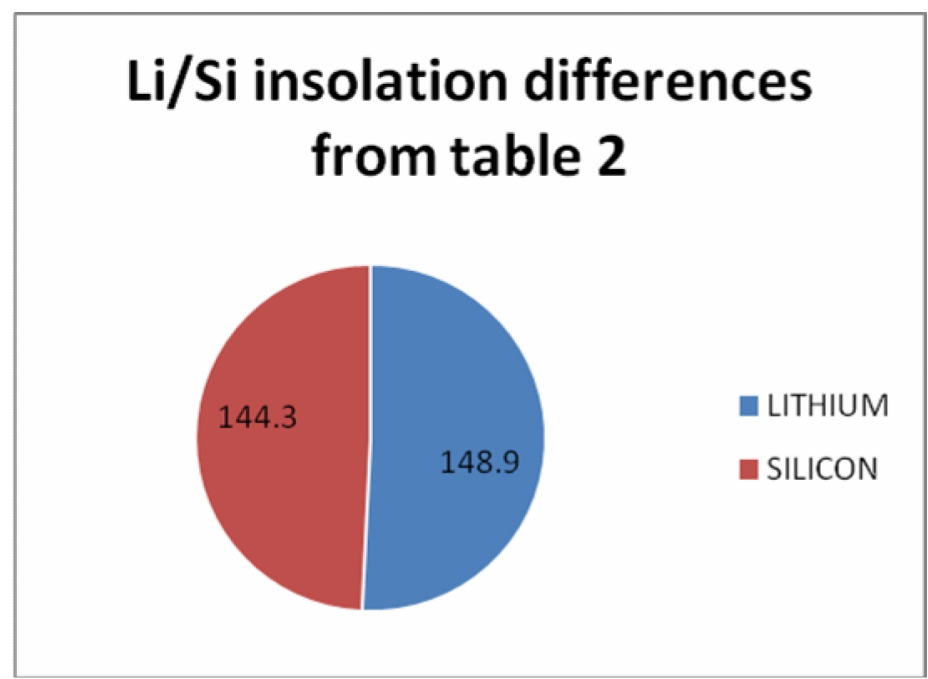

Figure 9

\section{$\mathrm{Li} / \mathrm{Si}$ insolation differences from table 3}

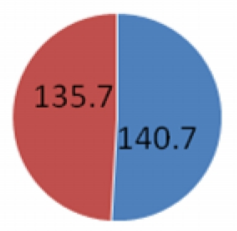

- LITHIUM

- SILICON

Figure 10

differences were found to be $\left(4.6 \mathrm{KW} / \mathrm{m}^{2}\right)$ which is large

Also from Figure 9, there is difference in insolation of $\left(4.6 \mathrm{kw} / \mathrm{m}^{2}\right)$ which Lithium has over Silicon and this is also a great difference that needs to be taken care of. The same thing in Figure 10, there is also a difference of $\left(5.0 \mathrm{kw} / \mathrm{m}^{2}\right)$ which Lithium has over Silicon. In general, we observed that there are great differences in all the three location that good enough to be considered, and a solution needs to be provided.

\section{CONCLUSION:}

In this Research, the potentiality of lithium element in terms of solar energy insolation, have been studied. And when comparing the results with that of silicon, the insolation amount of energy that Lithium absorbed over Silicon, and gives lithium priority to be used industrially over silicon, Also this result qualified Katsina state to be a very good location for solar power plant location, this is why, because the intensity of sun-energy is in good agreement with the standard surface solar irradiation (SSI) (6)

\section{RECOMMENDATION}

The results indicate that there is a great loss of energy when using the silicon as a material for solar cells. Therefore, its recommended that, the scientist should put more emphasis in the research of various elements that can take /replace silicon 
which used to degrade over a period of usage. Secondly, Government should establish a flat form between the researchers and industries so that whenever a good research is being made, it will be realized and be produce in a commercial quantity. Thirdly, we recommend that, lithium element should be given a priority over silicon due to it is durability and higher insolation power.

\section{ACKNOWLEDGEMENT}

The Researchers wishes to acknowledge the effort of tetfund for the full sponsorship of the research through it is programme: Institution Based Research Fund (IBR-Fund).

\section{REFERENCES}

[1] Nwokoye, A.O.C; "Measurement of global radiation constant (intensity) at Awka using pyranometer"Anarticle published in Nigerian Journal of Renewable Energy. Vol.II, Pp 1-8

[2] Okeke C.E; "Principles of the conversion of solar energy to electricity" An article published by NCERD, University of Nigeria, Nsukka (UNN) (2001).

[3] Dan shehu, B.G; "Effect of absorber orientation on the performance of solar flate plate collectors" An article published by Nigerian Journal of Renewable Energy. Vol.II (2004).

[4] Balarabe, M.A; "Variability of rainfall due to dust aerosol in katsina" A paper presented at the $8^{\text {th }}$ National conference organized by college of science and Technology, Hassan Usman Katsina Polytechnic Katsina (2004).

[5] Sambo, A.S; "Solar Radiation in Kano: a correlation with meteorological Data" Nigerian Journal of solar Energy. Vol. IV (1985).

[6] Iwuaha S.I; "System Design parameters for solar device in Imo state Nigeria, Nigerian Journal of Renewable Energy. Vol. II (2004).

[7] Hong Ch X, Zhang X L, et al. PSP pyranometer thermal offset characteristics and global radiation measurement error analysis [J]. Solar Technology, 2009, 30(1): 19-27

[8] Evaluation of Radiometers in Full-Time Use at the National Renewable Energy Laboratory Solar Radiation Research Laboratory[R]. NREL Report (2008) No. TP-550-44627

[9] Salisu, B; et al "A seven-day Field work solar radiation measuremen using Pyranometer device carried out at Daura, Funtua and Katsina. (2019) 